\title{
Modern Medicine: Creating Ethical Dilemmas and Overcoming Them
}

\section{Nandi Shah, Sukhpreet Kaur, Sandra Rome and Parag Bharadwaj*}

Palliative Care Program, Cedars- Sinai Medical Center,8700 Beverly Blvd., Room 2802,Los Angeles, CA 90048, USA

\section{Introduction}

Medical ethics is governed by the principles of doing no harm to patients and patient autonomy. Advances in treatments and technologies can pose ethical challenges for the physicians but also present opportunities to overcome them. One such area is the field of hematopoietic stem cell transplantation (HSCT). Patients with a diagnosis of a hematologic malignancy such as acute leukemia usually undergo a bone marrow transplant with the goal of a cure. Recent improvements in the technology of transplantation and supportive care have decreased mortality and improved outcome for patients, allowing application of this therapeutic and potentially curative strategy to sicker and older patients [1]. The treatment involves the infusion of stem cells, which usually reside in the bone marrow, into the patient. The stem cells are harvested either from the patient's own blood (autologous) or from a donor (allogeneic). Prior to the transplant, patients undergo induction chemotherapy to achieve remission. Throughout the treatment, patients are at high risk of developing anemia or complications, such as bleeding, which require multiple blood and platelet transfusions. A blood transfusion requires patient consent.

Jehovah's Witnesses are a Christian denomination. The key tenet of their faith is the non acceptance of blood transfusions of whole blood, red blood cells, white blood cells, platelets, or plasma [2]. This is based on the biblical reference, "Abstain... from blood" -Acts 15:20 [3]. The belief is that once blood is removed from the body, it cannot be returned to the body, regardless of the source of the blood i.e. their own or from others. Transfusion of stem cells, blood fractions including clotting factors, interferons, and platelet-derived wound healing factors are acceptable to most Jehovah's Witnesses. Bloodless medicine combines use of drugs, equipment, and surgical techniques to reduce blood loss and increase patient's blood production to avoid hemorrhage or anemia [4].

Since patients who follow this faith do not want to be transfused, it poses a challenge to physicians. Most patients are declined a transplant due to concern of patient mortality from the lack of transfusion. The principles of patient autonomy, their right to decline a blood transfusion, and the physicians responsibility to cause no harm come into direct conflict at this point [2].

Dr. Michael Lill, Director of the BMT program at Cedars- Sinai Medical Center's Samuel Oschin Comprehensive Cancer Center has been performing HSCT on Jehovah's Witnesses patients since 1999 without blood transfusions. Prior to transplanting the patients, their personal preferences and beliefs are discussed in order to tailor treatments accordingly. Dr. Lill has performed approximately 40 autologous and 10 allogeneic transplants in Jehovah's Witness patients without blood transfusions. He recognizes this risk of refusing blood transfusions, but Dr. Lill does not question their faith or decision to decline transfusions. Rather, a goal of patient autonomy is his driving ethical parameter. Patients with acute leukemia undergoing induction therapy have been severely anemic during the treatment, with hemoglobin levels falling to as low as 2 . This is an immediately life threatening level of anemia, and warrants transfusions of multiple units of blood. Understanding the risks, the patient's autonomy is respected and they are given the right to refuse a simple and a seemingly routine intervention. In his experience, Dr. Lill has not had a single mortality related to anemia in transplant population, although induction therapy for acute leukemia is much more of a challenge, with a much poorer outcome. What was once considered an oddity by his team of physicians, nurses and pharmacists is now routine practice? Dr. Lill is one of the few physicians in the world to undertake such a challenge. At present, he has a patient who flew in from another region of the world to seek treatment since physicians in his home country refused to perform the transplant without a transfusion.

\section{Conclusion}

The duty of a physician is not simply to preserve life, but also to respect a patient's beliefs. Jehovah's Witness patients do not accept whole blood transfusions, and Dr. Michael Lill has developed an approach that respects the patients' autonomous decision. He is able to perform both autologous and allogeneic bone marrow transplants without red blood cell, or platelet transfusion. Such bold undertakings allow patients to receive treatments for potentially curable diseases to which they may otherwise succumb. This is a prime example where advances in clinical science pose challenges, but also opportunities that can be overcome without compromising the ethical principles of either the patient, or the physician.

\section{References}

1. Pasquini MC, Wang Z, Horowitz MM, Gale RP (2010) 2010 report from the Center for International Blood and Marrow Transplant Research (CIBMTR): current uses and outcomes of hematopoietic cell transplants for blood and bone marrow disorders. Clin Transpl 87: 105.

2. Smith ML (1997) Ethical perspectives on Jehovah's Witnesses' refusal of blood. Cleve Clin J Med 64: 475-481.

3. Anonymous. (1990)How Can Blood Save Your Life? New York: Watchtower Bible and Tract Society of New York.

4. Mann MC, Votto J, Kambe J, McNamee MJ (1992) Management of the Severely Anemic Patient Who Refuses Transfusion: Lessons Learned during the Care of a Jehovah's Witness. Ann Intern Med 117: 1042-1048.

*Corresponding author: Parag Bharadwaj, Medical Director, Palliative Care Program, Cedars- Sinai Medical Center,8700 Beverly Blvd., Room 2802,Los Angeles, CA 90048, USA, E-mail: paragbharadwaj@hotmail.com

Received June 14, 2012; Accepted June 18, 2012; Published June 21, 2012

Citation: Shah N, Kaur S, Rome S, Bharadwaj P (2012) Modern Medicine: Creating Ethical Dilemmas and Overcoming Them. J Clinic Res Bioeth 3:e108. doi:10.4172/2155-9627.1000e108

Copyright: ( 2012 Shah N, et al. This is an open-access article distributed under the terms of the Creative Commons Attribution License, which permits unrestricted use, distribution, and reproduction in any medium, provided the original author and source are credited. 